\title{
The effect of autonomous learning process on learner autonomy of English public speaking students
}

\author{
Nida Boonma ${ }^{1^{*}}$ and Rosukhon Swatevacharkul ${ }^{2}$ \\ ${ }^{1}$ Business English Department, Theodore Maria School of Arts, Assumption University, \\ Sumutprakarn 10570, Thailand \\ ${ }^{2}$ English Language Teaching Program, Graduate School of Human Sciences, Assumption University, \\ Bangkok 10240, Thailand
}

\begin{tabular}{|c|c|}
\hline \multirow{2}{*}{\multicolumn{2}{|c|}{$\begin{array}{l}\text { ABSTRACT } \\
\text { The objectives of this study were to examine the effect of the autonomous learning process (ALP) } \\
\text { on learner autonomy of undergraduate students in English public speaking class and its effect } \\
\text { size; and to explore how learner autonomy is revealed through the ALP. This study employed a } \\
\text { variant of a mixed-methods approach, which is an embedded experimental design. Employing the } \\
\text { cluster sampling method, nineteen Thai students were included. The students were trained in the } \\
\text { ALP based on the four dimensions of learner autonomy (technical, psychological, political- } \\
\text { critical, and sociocultural.) Quantitative data were collected from the Learner Autonomy for } \\
\text { Public Speaking (LAPS) questionnaires and analyzed by the dependent samples t-test. Qualitative } \\
\text { data were drawn from the Overall Written Reflections, and thematic content analysis was used to } \\
\text { analyze the data. The findings revealed that the level of students' learner autonomy in the post- } \\
\text { questionnaire significantly increased from the pre-questionnaire (p = 0.00). Its effect size is large } \\
\text { (d = 1.28), and learner autonomy, as revealed through the ALP, can be classified into five } \\
\text { emerging themes. The themes are (1) use and plans of the learning strategies, (2) evaluation of } \\
\text { learning and learning strategies, (3) capacity to provide and accept praise and criticism, (4) } \\
\text { increased positive emotions and (5) sense of awareness and a better understanding of self. } \\
\text { Recommendations for further study are provided. } \\
\text { Keywords: Autonomous learning process; English language teaching; learner autonomy; public } \\
\text { speaking ability; reflection practices }\end{array}$}} \\
\hline & \\
\hline $\begin{array}{c}\text { Revised: } \\
23 \text { February } 2020\end{array}$ & 31 May 2020 \\
\hline \multicolumn{2}{|c|}{$\begin{array}{l}\text { How to cite (in APA style): } \\
\text { Boonma, N. \& Swatevacharkul, R. (2020). The effect of autonomous learning process on } \\
\text { learner autonomy of English public speaking students. Indonesian Journal of Applied } \\
\text { Linguistics, } 10(1), 194-205 . \text { https://doi.org/10.17509/ijal.v10i1.25037 }\end{array}$} \\
\hline
\end{tabular}

\section{INTRODUCTION}

English speaking ability is viewed as a challenge for Thai students, and public speaking ability poses a much greater impediment. One of such challenges is public speaking anxiety, which is considered by many as one of the greatest fears. Speech anxiety can be described as “an individual's level of fear or anxiety associated with real or anticipated communication with another person or persons" (McCroskey, 1977, p. 78). For Thai classrooms, students are observed to be unwilling and have low confidence to communicate in English due to anxiety
(Boonkit, 2010; Chinpakdee, 2015). Such anxiety is derived from the notion that Thai is predominantly used in and outside of class. English communication skills development is, therefore, problematic for language classrooms (Sa-Ngiamwibool, 2010; Suwannopharat \& Chinokul, 2015).

Moreover, to comply with Thailand Qualification Framework (TQF), which called for learner-centered classrooms (National Qualifications Framework for Higher Education in Thailand, 2006), there is a need to integrate autonomous learning process (ALP) into the classrooms. Indeed, learner

\footnotetext{
* Corresponding Author

Email: nidabnm@au.edu
} 
autonomy is considered as one of the desirable educational goals (Benson, 2007; Borg, 2012; Cotteral, 1995; Ramadhiyah \& Lengkanawati, 2019; Reinders \& White, 2016).

For public speaking classrooms, it is believed that learner autonomy can be applied. To clarify, individual public speaking tasks depend upon the students' responsibility and capacity to manage their own learning in preparation and rehearsals of their speeches in and out of classes. The goal of the ALP is not only to develop students' English public speaking ability but also to foster the learner autonomy. As discussed in Boonma and Swatevacharkul (2018), the effect of the ALP on the students' public speaking ability is that the scores of the post-test speech are significantly higher than the scores of the pre-test speech $(p=0.00)$. In this study, the aim is to further present the findings on the effect of ALP on learner autonomy and how learner autonomy is revealed in the English public speaking classroom.

The notion of learner autonomy can be traced to learner-centered approaches originating in the 1970 s (Benson, 2012). It is believed that students are active participants in their own learning processes in the learner-centered classroom environment (Nunan \& Lamb, 2001). Such active participation in the learning entails the students' responsibility in their knowledge creation based on their discovery (Knowlton, 2000; Nunan, 1999). Specifically, in the context of language classrooms, the aims of learner autonomy are to achieve both language goal and learning process goals (Nunan \& Lamb, 2001). Undeniably, learner-centered approaches are connected to learner autonomy pedagogy.

As defined by Holec (1981), learner autonomy refers to "the ability to take charge of their own learning” (p. 3), which denotes students' responsibility in every aspect of their learning process. Benson (2011) further defined Holec's learner autonomy as "the capacity to take control of one's own learning" (p. 58) because the construct "control" is more open to an investigation than Holec's constructs of "charge" and "responsibility." In a practical sense, for learner autonomy development, learner training is believed to be an integral part of learner autonomy pedagogy (Smith 2008). Precisely, according to Wenden (1991), the use of learning strategies should be explicitly trained to the students as it can lead to learner autonomy.

Since definitions of learner autonomy are believed to be complex and varied, learner autonomy is often viewed as multidimensional (Benson, 1997; Little, 1991; Pennycook, 1997). A number of models of learner autonomy were also developed (Benson, 1997; Littlewood, 1996; Macaro, 1997; Oxford, 2003). However, the most comprehensive is Oxford's (2003), which is an expansion of Benson's (1997). Oxford's (2003) model of language learner autonomy encompasses four dimensions as summarized in
Boonma and Swatevacharkul (2018) as (1) Technical dimension where autonomy is viewed as the language skills and strategies conducive for independent learning situations; (2) Psychological dimension focuses on the combination of learners' attitude and emotion; (3) Political-critical dimension focuses on learners' self and identity which is in line with Pennycook (1997) who suggested that development of autonomy involves learners becoming the owner of their own world; and (4) Sociocultural dimension, in which learner autonomy is developed through interdependence and social mediated learning processes (Benson, 2007).

Keeping in mind the interconnectedness of each dimension described above, this study was set out to examine learner autonomy in the English public speaking class from all four dimensions.

To develop English public speaking ability, the students are required to have not only speaking ability, but also motivation to speak, critical thinking skills, creativity, and social interaction skills to captivate the audience. This way, learner autonomy can be applied to public speaking classrooms as the students' capacity to manage their own learning is vital. Individually, for each speech, students need to demonstrate their capacity in topic selection, speech outline planning, contents, and speaking notes preparation, rehearsals, and speech delivery. However, studies regarding learner autonomy and public speaking ability remain limited (Everhard, 2015; Yamkate \& Intratat, 2012).

The available research on public speaking in Thailand is largely in the area of speech anxiety. Findings from many studies revealed that speech anxiety could be prevalent regardless of proficiency or perceived proficiency level (Plangkham \& Porkaew, 2012). Moreover, Thai students feel inept when speaking in the public setting, especially with strangers (Dilbeck et al., 2009). Despite the increasing effort from universities in Thailand to offer English public speaking courses to develop Thai students' public speaking ability, students incline to enroll in a speaking course as they dread giving a speech even for the classroom (Plangkham \& Porkaew, 2012).

To fill the gap, as studies regarding learner autonomy and public speaking ability in the Thai context are scarce, the ALP for English public speaking ability central to this study was developed as a pedagogical tool. Indeed, to foster students to become autonomous, learner training or learning strategy training plays a vital role in the ALP (Little, 1995).

The ALP in this context is a synthesis of dimensions of learner autonomy (based on Benson, 1997; Murase, 2015; Oxford, 2003), and related literature on public speaking ability. For this study, the ALP is defined as a learning process for English public speaking ability involving learner training in four dimensions of learner autonomy which are 
technical, psychological, political-critical, and sociocultural through reflection activities: written self-reflection, written peer feedback, and group interactive feedback.

Incorporating all four dimensions of learner autonomy in a holistic manner in the English public speaking class, it is believed that the students should be trained to use, monitor, and plan their learning strategies (Technical Dimension), to manage their anxiety (Psychological Dimension), to creatively and critically deliver the speech (Political-Critical Dimension) and to engage their audience (Sociocultural Dimension).

The ALP training can be explained as: (1) prespeaking training: cognitive and affective strategy training in order to prepare, rehearse, deliver the speeches, and manage anxiety before each speech; (2) whole semester training: activities to develop students' confidence, motivation, creativity, critical thinking skills, and collaboration; and (3) postspeaking training or reflection training: metacognitive and social strategy training so as to self-reflect, write and obtain peer feedback, and participate in the Group Interactive Feedback (GIF) sessions after each speech.

The ALP Framework is summarized in Figure 1. More detailed descriptions of the framework and the training can be found in Boonma (2016) and Boonma and Swatevacharkul (2018).

\section{Figure 1}

ALP for English Public Speaking Ability Framework

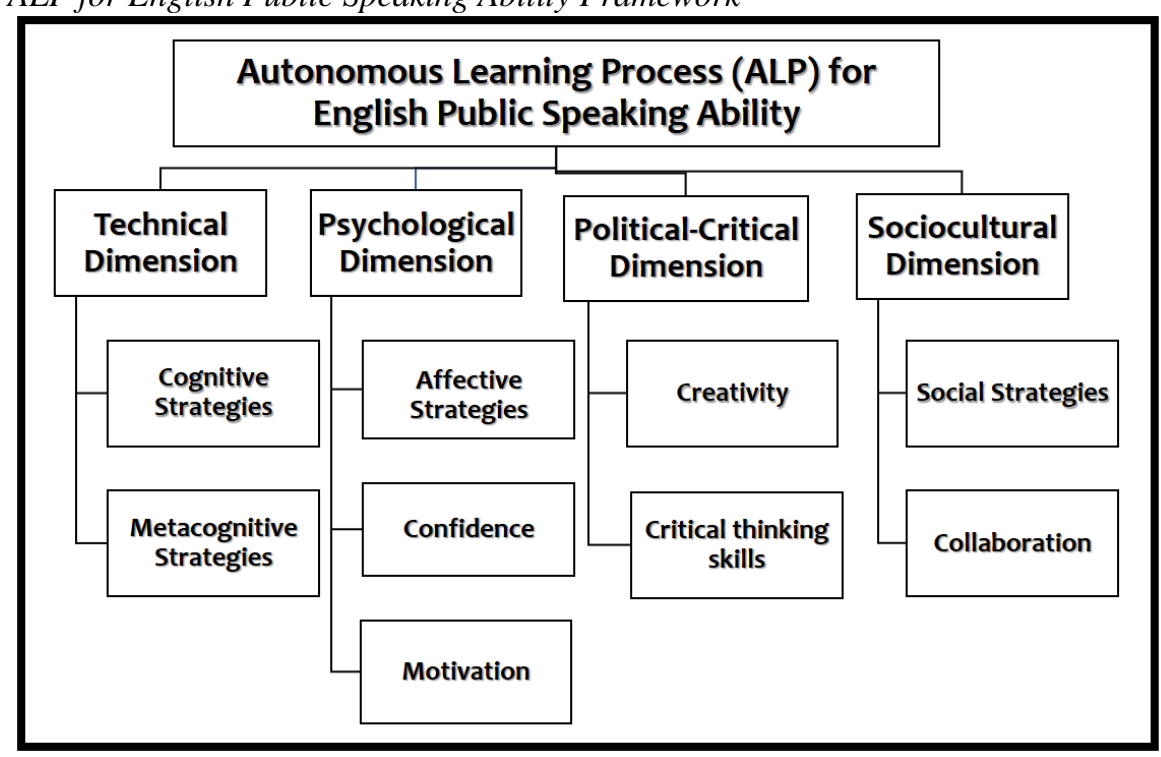

Therefore, the research questions of the study are: (1) What is the effect of autonomous learning process (ALP) on learner autonomy of Thai undergraduate students in English public speaking class?; and (2) How is learner autonomy revealed through ALP in English public speaking class?

Research hypothesis corresponding to the first research question is: Through the intervention of ALP, the level of students' learner autonomy for English public speaking ability in the postquestionnaire will significantly increase from the prequestionnaire $(\mathrm{p}=0.05)$.

\section{METHOD}

This study employed a variant of mixed methods approach which is an embedded experimental design (Figure 2). For this research design, a qualitative strand (qual) is embedded within a quantitative experiment (QUAN) to supplement the experimental design (Creswell \& Plano Clark, 2011). During the intervention, qualitative data were collected from students' reflections. The subsequent reflections after the implementation of ALP were gathered to provide more insight into the quantitative findings.

The population of the study consisted of students enrolling in 12 sections (226 students) of English Public Speaking class in an undergraduate international program during the Semester 1/2017 (August-November 2017). A cluster sampling method was employed to select only one section. As the scope of the study is Thai students only, all 19 Thai students in the section (out of 20) were included as the subjects of the study.

Quantitative data were obtained utilizing the 5point Likert scale. Learner Autonomy for Public Speaking Ability (LAPS) Questionnaire was developed based on Cohen et al.(2002), Murase (2015) and Oxford (1990) and related literature. The questionnaire consisted of 42 statements in four dimensions of learner autonomy. Its content validity is 0.80 and the Cronbach's alpha is 0.95 . The prequestionnaire was administered on Week 1 and the post-questionnaire was administered at Week 15.

Moreover, qualitative data were gathered through the Overall Written Reflections to explore 
how learner autonomy is revealed in the ALP. Students were trained to reflect on: speech preparation, speech rehearsal, speech delivery, peer feedback received, and feedback given to others. The content validity of the 14 guided questions for the reflections is 0.84 . The first overall written reflections were collected on Week 8 after the

\section{Figure 2}

Research Design

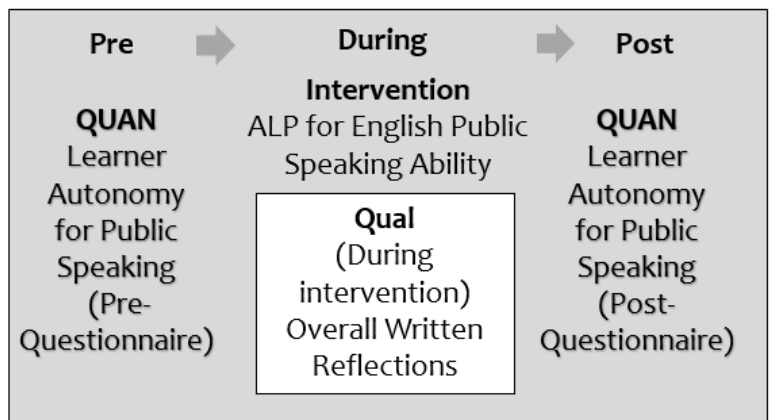

The steps involved in the mixed-methods (embedded design) are suggested by Creswell and Plano Clark (2011). For this study, after the quantitative (the LAPS Questionnaire) and qualitative data (Overall Written Reflections) were analyzed, the emerging themes from the embedded completion of two informative speeches and the second were at Week 14 after the completion of two persuasive speeches. Thematic content analysis was employed, and intercoder reliability was ensured. Spearman's Rho was 1.00 for the first Overall Written Reflection and 0.99 for the second Overall Written Reflection.

\section{Figure 3}

Mixed-Methods Research Procedures

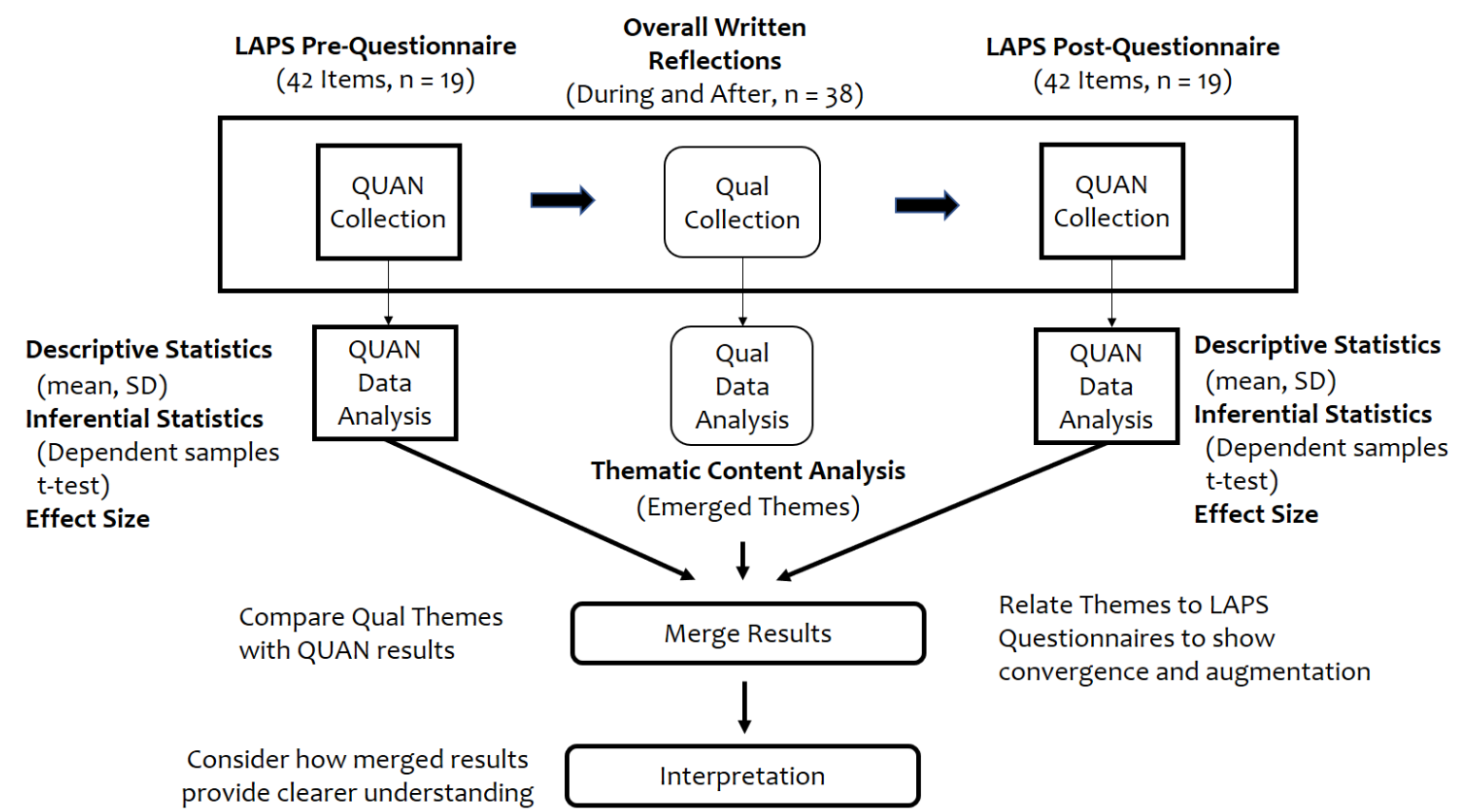

\section{RESULTS}

\section{The effect of ALP on learner autonomy}

To answer the first research question, the dependent samples t-test was calculated to test the hypothesis. It was found that the level of learner autonomy for public speaking ability in the post-questionnaire was significantly higher than the level of the prequestionnaire $(\mathrm{t}(18)=5.56, \mathrm{p}<0.05)($ Table 1$)$. The hypothesis is accepted. 
Table 1

Statistical Test of Mean of the LAPS Questionnaire

\begin{tabular}{lcccccccc}
\hline LAPS Questionnaire & $\mathbf{n}$ & Mean & SD & $\begin{array}{c}\text { Level of Learner } \\
\text { Autonomy }\end{array}$ & $\begin{array}{c}\text { Mean } \\
\text { Gain }\end{array}$ & t & df & $\begin{array}{c}\text { Sig. (One- } \\
\text { tailed) }\end{array}$ \\
\hline $\begin{array}{l}\text { Pre-questionnaire } \\
\text { Post-questionnaire }\end{array}$ & 19 & 3.51 & 0.43 & Moderate & 0.51 & 5.56 & 18 & 0.00 \\
\hline
\end{tabular}

The effect size (ES) calculation of the ALP on learner autonomy suggested that Cohen's $d$ is 1.28 . Thus, the magnitude of the effect is large. This can be inferred that a probability that a student's score sampled at random from the post-questionnaire will be greater than a student's score sampled from the pre-questionnaire is 0.80 (McGraw \& Wong, 1992).
The students' mean scores on the questionnaires were further examined. It can be seen that the students' level of learner autonomy improved from moderate $($ Mean $=3.51, \mathrm{SD}=0.43)$ to high $($ Mean $=$ 4.02, $\mathrm{SD}=0.48)$ after the ALP implementation. Comparisons between each dimension of learner autonomy are shown in Table 2.

Table 2

Statistical Comparisons of the LAPS Questionnaire Based on Dimensions of Learner Autonomy

\begin{tabular}{lllllccccc}
\hline \multicolumn{1}{c}{ Dimensions } & & $\mathbf{n}$ & Mean & SD & Level & $\begin{array}{c}\text { Mean } \\
\text { Gain }\end{array}$ & t & $\begin{array}{c}\text { Sig. (One- } \\
\text { tailed) }\end{array}$ \\
\hline \multirow{2}{*}{ Technical } & Pre & 19 & 3.49 & 0.41 & Moderate & 0.61 & 6.16 & 18 & 0.00 \\
& Post & 19 & 4.10 & 0.52 & High & & & & \\
Psychological & Pre & 19 & 3.31 & 0.46 & Moderate & 0.58 & 5.40 & 18 & 0.00 \\
\multirow{2}{*}{ Political-Critical } & Post & 19 & 3.89 & 0.56 & High & & & & \\
\multirow{2}{*}{ Sociocultural } & Pre & 19 & 3.82 & 0.62 & High & 0.36 & 2.68 & 18 & 0.00 \\
& Post & 19 & 4.18 & 0.61 & High & & & & \\
\end{tabular}

The dependent samples t-test revealed that the post-questionnaire scores significantly increased from the pre-questionnaire in all four dimensions ( $p$ $=0.00$ ). From the post-questionnaire, the highest was in Political-Critical and followed by Technical, Sociocultural and Psychological. Furthermore, by comparing questionnaire mean gain, it can be seen that the students improved the most in the Technical (0.61), Psychological (0.58), Sociocultural (0.39), and Political-Critical Dimension (0.36) respectively. The dependent samples t-test was also calculated for each sub-dimension. It was indicated that the level of autonomy significantly increased in all subdimensions $(\mathrm{p}<0.05)$, as displayed in Table 3 to Table 6.

For Technical dimension, students' level of autonomy with regards to cognitive strategies is high in both pre- and post-questionnaires. For metacognitive strategies, the students' level also significantly increased from moderate to high. Therefore, students used metacognitive strategies at a lower level than cognitive strategies before the implementation of ALP and used at a similar level afterward.

Table 3

Statistical Comparisons of LAPS Questionnaire: Technical Dimension

\begin{tabular}{|c|c|c|c|c|c|c|c|c|c|}
\hline \multicolumn{2}{|c|}{ Technical Dimension } & $\mathbf{n}$ & Mean & SD & Level & $\begin{array}{c}\text { Mean } \\
\text { Gain }\end{array}$ & $\mathbf{t}$ & df & $\begin{array}{l}\text { Sig. (One- } \\
\text { tailed) }\end{array}$ \\
\hline Cognitive & Pre & 19 & 3.83 & 0.55 & High & \multirow{2}{*}{0.35} & \multirow{2}{*}{3.38} & \multirow{2}{*}{18} & \multirow{2}{*}{0.00} \\
\hline Strategies & Post & 19 & 4.18 & 0.59 & High & & & & \\
\hline Metacognitive & Pre & 19 & 3.12 & 0.50 & Moderate & \multirow{2}{*}{0.89} & \multirow{2}{*}{5.75} & & \multirow{2}{*}{0.00} \\
\hline Strategies & Post & 19 & 4.01 & 0.58 & High & & & 18 & \\
\hline
\end{tabular}

For Psychological dimension, in all three subdimensions, students reported a moderate level of learner autonomy in the pre-questionnaire, and the level significantly increased to a high level in the post-questionnaire (Table 4).

In Political-Critical dimension, the level of learner autonomy significantly increased but remained within the same level as high for both preand post-questionnaire (Table 5). This means the increase after the implementation of ALP, although significant, was not as drastic as other dimensions discussed previously.
For Sociocultural dimension, students' level of autonomy concerning social strategies significantly increased from moderate to high while the level of collaboration significantly increased from high to very high (Table 6). Indeed, the level of collaboration after the implementation of ALP was the highest among all sub-dimensions. In sum, the findings indicated that the level of students' learner autonomy for public speaking ability after the ALP implementation increased from moderate to high level. Indeed, the students' level of learner autonomy increased in all dimensions and subdimensions of learner autonomy. 
Table 4

Statistical Comparisons of LAPS Questionnaire: Psychological Dimension

\begin{tabular}{|c|c|c|c|c|c|c|c|c|c|}
\hline \multicolumn{2}{|c|}{ Psychological Dimension } & \multirow{2}{*}{$\begin{array}{c}\mathbf{n} \\
19\end{array}$} & \multirow{2}{*}{$\begin{array}{c}\text { Mean } \\
3.24\end{array}$} & \multirow{2}{*}{$\begin{array}{c}\text { SD } \\
0.69\end{array}$} & \multirow{2}{*}{$\begin{array}{c}\begin{array}{c}\text { Level of } \\
\text { Learner } \\
\text { Autonomy }\end{array} \\
\text { Moderate }\end{array}$} & \multirow{3}{*}{$\begin{array}{c}\begin{array}{c}\text { Mean } \\
\text { Gain }\end{array} \\
0.56\end{array}$} & \multirow{3}{*}{$\begin{array}{c}\mathbf{t} \\
3.07\end{array}$} & \multirow{3}{*}{$\begin{array}{l}\text { df } \\
18\end{array}$} & \multirow{2}{*}{$\begin{array}{c}\begin{array}{c}\text { Sig. (One- } \\
\text { tailed) }\end{array} \\
0.00\end{array}$} \\
\hline Affective & Pre & & & & & & & & \\
\hline Strategies & Post & 19 & 3.80 & 0.66 & High & & & & 0.00 \\
\hline \multirow{2}{*}{ Confidence } & Pre & 19 & 3.28 & 0.57 & Moderate & \multirow{2}{*}{0.43} & \multirow{2}{*}{3.27} & \multirow{2}{*}{18} & \multirow{2}{*}{0.00} \\
\hline & Post & 19 & 3.71 & 0.67 & High & & & & \\
\hline \multirow{2}{*}{ Motivation } & Pre & 19 & 3.40 & 0.70 & Moderate & \multirow{2}{*}{0.76} & \multirow{2}{*}{4.99} & \multirow{2}{*}{18} & \multirow{2}{*}{0.00} \\
\hline & Post & 19 & 4.16 & 0.66 & High & & & & \\
\hline
\end{tabular}

Table 5

Statistical Comparisons of LAPS Questionnaire: Political-Critical Dimension

\begin{tabular}{llcccccccc}
\hline \multicolumn{2}{c}{ Sub-dimensions } & n & Mean & SD & Level & $\begin{array}{c}\text { Mean } \\
\text { Gain }\end{array}$ & t & $\begin{array}{c}\text { Sig. (One- } \\
\text { tailed) }\end{array}$ \\
\hline Creativity & Pre & 19 & 3.79 & 0.65 & High & 0.37 & 2.11 & 18 & 0.02 \\
Critical Thinking & Post & 19 & 4.16 & 0.69 & High & & & & \\
Skills & Pre & 19 & 3.83 & 0.72 & High & 0.37 & 2.28 & 18 & 0.02 \\
\hline
\end{tabular}

Table 6

Statistical Comparisons of LAPS Questionnaire: Sociocultural Dimension

\begin{tabular}{llcccccccc}
\hline \multicolumn{2}{c}{ Sub-dimensions } & n & Mean & SD & Level & $\begin{array}{c}\text { Mean } \\
\text { Gain }\end{array}$ & t & df & $\begin{array}{c}\text { Sig. (One- } \\
\text { tailed) }\end{array}$ \\
\hline \multirow{2}{*}{ Social Strategies } & Pre & 19 & 3.41 & 0.57 & Moderate & 0.29 & 2.19 & 18 & 0.02 \\
\multirow{2}{*}{ Collaboration } & Post & 19 & 3.70 & 0.66 & High & & & & \\
& Pre & 19 & 3.96 & 0.58 & High & 0.55 & 4.19 & 18 & 0.00 \\
\hline
\end{tabular}

Revelation of learner autonomy in the English public speaking classroom

To answer the second research question, the data collected from students' two Overall Written Reflections (collected at Week 8 and Week 15) were analyzed employing thematic content analysis. The coded data were quantified by counting and converting into percentage to determine the frequency of each category and themes as to how learner autonomy was revealed through ALP.

The quantified qualitative results from the two Overall Written Reflections are presented side by side in accordance to the five emerging themes in Table 7.

Table 7

Quantified Results from Five Emerged Theme

\begin{tabular}{|c|c|c|c|c|c|c|}
\hline & \multirow{2}{*}{ Theme } & \multicolumn{2}{|c|}{$1^{\text {st }}$ Reflection } & \multicolumn{2}{|c|}{$2^{\text {nd }}$ Reflection } & \multirow{2}{*}{$\begin{array}{c}\% \\
\text { Gain }\end{array}$} \\
\hline & & Count & $\%$ & Count & $\%$ & \\
\hline 1) & Use and plans of the learning strategies & 181 & 25.64 & 142 & 23.28 & -2.36 \\
\hline 2) & Evaluation of learning and learning strategies & 174 & 24.65 & 163 & 26.72 & 2.08 \\
\hline 3) & $\begin{array}{l}\text { Capacity to provide and accept ideas, praise, } \\
\text { and criticism with sensitivity }\end{array}$ & 164 & 23.23 & 137 & 22.46 & -0.77 \\
\hline 4) & $\begin{array}{l}\text { Increased positive emotions as compared to } \\
\text { negative emotions }\end{array}$ & 105 & 14.87 & 92 & 15.08 & 0.21 \\
\hline \multirow[t]{2}{*}{ 5) } & $\begin{array}{l}\text { Sense of self-awareness and better } \\
\text { understanding of self }\end{array}$ & 82 & 11.61 & 76 & 12.46 & 0.84 \\
\hline & Total & 706 & 100.00 & 610 & 100.00 & \\
\hline
\end{tabular}

On the outset, it appears that the students reflected slightly less in frequency in the second reflection than on the first one. It can be explained that the students tend to reflect more on the points of improvements. Since there were more improvements on the first half the semester, the students reflected more on the first reflections.

Some of the excerpts in relations to the emerging themes are presented here.
Theme 1: Use and plans of the learning strategies: "I plan to practice more, especially practice without using the script. Moreover, I will record the video while practicing so I can see myself." (Student \#3)

"I will ask my friends to listen to my speech while practicing and I will practice with the podium, so it seems like I deliver the real speech." (Student \#9) 
Theme 2: Evaluation of learning and learning strategies:

"I think I can control myself more in the second speech because I read the script less than the first speech." (Student \#10)

"Seeing myself in the video, I have seen many mistakes... I looked (my non-verball posture) too excited during the speech." (Student \#18)

Theme 3: Capacity to provide and accept ideas, praise, and criticism with sensitivity:

"...never write only negative comments because that will hurt my friends' feelings. I learned that my comments will be useful to give how to improve" (Student \#15)

"I've learned to use appropriate language for suggestions. I think before I write because strong language, even if it is true, it will hurt them. For compliments, I learned to give specific details, so they can understand." (Student \#16)

Theme 4: Increased positive emotions as compared to negative emotions:

"I am not nervous and very satisfied with my rehearsal as
I wish I could present like I practice." (Student \#3)

"I feel good when I practice. I feel confident and can remember everything when I practice." (Student \#12)

Theme 5: Sense of self-awareness and better understanding of self:

"I have learned that I cannot be so full of myself as I still have many errors which need to be improved." (Student \#13)

"I learned a lot about myself that I didn't know or didn't see about before." (Student \#14)

Mixed-Methods results: Convergence of the results

The findings from the questionnaire suggested that the students improved in all dimensions of learner autonomy. All four dimensions are also revealed from the five emerging themes. Thus, the two data sets were determined as convergence. Learner autonomy as revealed in the ALP is summarized in Figure 4.

Figure 4

Summary of Learner Autonomy as Revealed from the Emerging themes

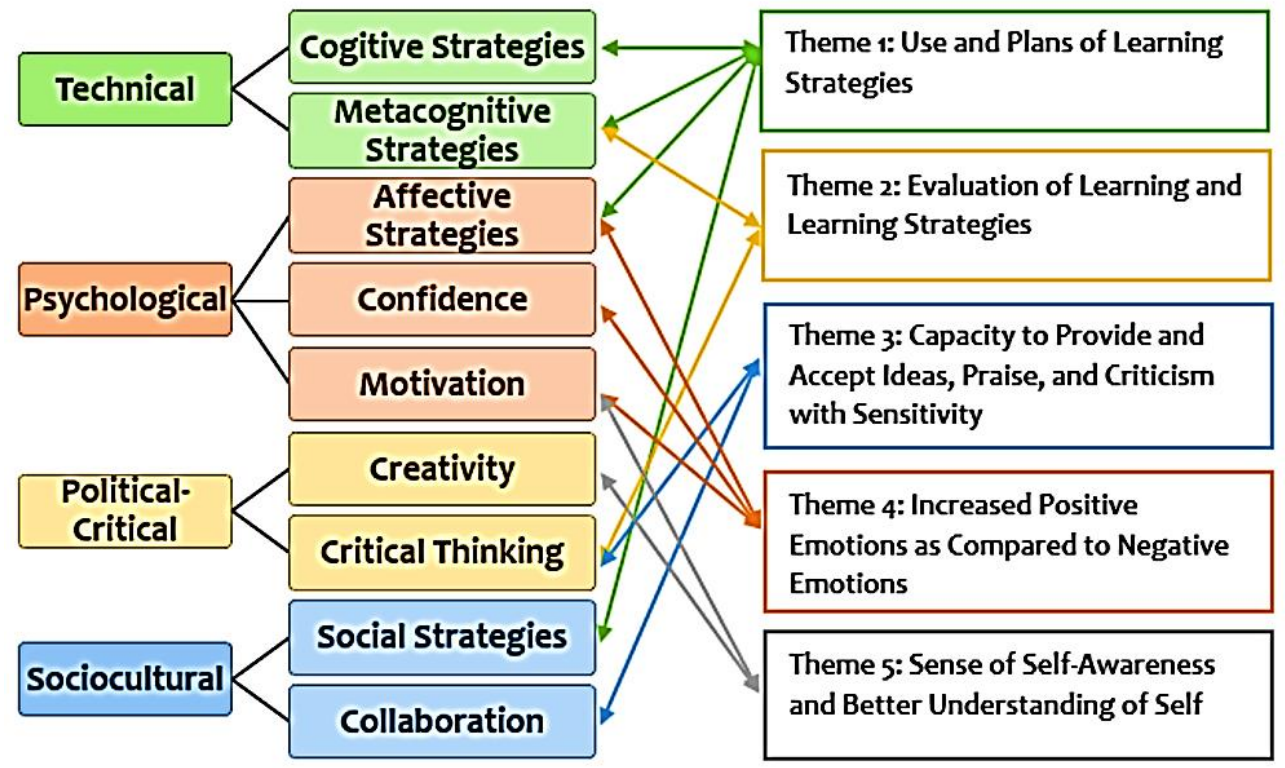

The emerging themes are explained in relations to the dimensions of learner autonomy as follows:

First, for Technical dimension, the emerging themes suggested the students' use and plans of cognitive strategies (Theme 1). Students also described their metacognitive strategy used as they evaluated their learning and learning strategies involved in the speech training and reflection training during the ALP training (Theme 2). Throughout the ALP training, students were engaged in trial and errors with the varying learning strategies. Students were aware of their learning strategy use and were able to select the learning strategies suitable for the undertaking tasks. Since the highest frequencies of the emerging themes are in Theme 1 and Theme 2, it is corresponding to the highest improvement in the Technical dimension on the LAPS questionnaire. Thus, the results are in convergence.

Second, in Psychological dimension, from the first and the second reflections, the students appeared to have increased control over their emotions which signified the use of affective strategies (Theme 1). Evidently, students reflected more positive emotions than negative emotions. They also reported more confidence in the second reflections (Theme 4). Motivation was only evident in the students' reflection regarding their motivation to select the topics for their speeches as they expressed their 
passion (Theme 5). More importantly, the students disclosed much more positive emotions towards public speaking ability after the ALP implementation in line with the questionnaire findings.

Third, for Political-Critical dimension, creativity was found in students' reflection when students described how they searched within themselves for the speech topics or added personalization to the speech contents to offer new perspectives to the audience (Theme 5). Related to creativity, critical thinking skills was also evident in as students engaged in critical thinking in the evaluation of the speech contents and peer feedback contents (Theme 3). In this sense, they used their critical thinking skills to justify the accuracy of the information presented to them.

Fourth, for Sociocultural dimension, students used and planned to use social strategies mostly in the speech preparation and rehearsal (Theme 1). The findings also suggested that the Group Interactive Feedback (GIF) sessions (or verbal reflection in small groups) during the ALP contributed to the students' use of social strategies in the topic selection and speech rehearsal process. In addition, students were sensitive to others' feelings when providing praise and criticism (Theme 3). Students described that intention of the peer feedback writing was to help others improve which was the cultivation of collaboration among students (Theme 3).

\section{DISCUSSIONS AND IMPLICATIONS Learning strategies as a prerequisite of learner autonomy}

The findings from the Theme 1 and the questionnaire both suggested the significant increase of learning strategy use which implies that learning strategies are a prerequisite of learner autonomy. The study's findings are aligned with Nakatani's (2005) which revealed that cognitive and metacognitive strategy training can significantly improve the students' oral proficiency test scores.

For learners to develop autonomous learning behaviors, the capacity to utilize learning strategies is fundamental (Benson, 1997; Macaro, 1997; Murase, 2015). Thus, it is believed that learning strategies are considered a prerequisite of learner autonomy. Learner training is viewed as a helpful resource to enable students to be more active in the classrooms (Dickinson, 1992) and the effective use of learning strategies is linked to higher levels of achievement in a second language (Gardner \& MacIntyre, 1992). Indeed, the increase of learning strategy use can be observed from the types of the speeches. The types of the speeches which could enhance the use and plans of the learning strategies are persuasive speeches and prepared speeches.

Compared to informative speeches, persuasive speeches indeed required higher effort in credibility building as well as the effort in supporting or refuting claims. Cognitive strategies are especially required in order to convince the audience. Moreover, contrary to the impromptu speeches where speakers were given no preparation time, in the ALP, students delivered prepared speeches. For prepared speeches, the students invested their time and effort into the supporting material preparation as well as speech rehearsals. The findings from the questionnaire indicated that students improved in the preparation and the practice of words and expressions which is a result of use of the metacognitive strategies.

The implication is that informative speeches should be trained as a steppingstone for persuasive speeches because cognitive and metacognitive strategies are more developed than others from the persuasive speeches. The second implication is that the speeches should be prepared rather than impromptu. The time and effort invested in the preparation and the rehearsal can certainly foster the students' autonomous learning behaviors which result in the higher level of learner autonomy.

\section{Capacity to reflect and formation of the reflective behaviors}

The second reason for the learner autonomy development is that the ALP capacitates the students' reflection from multisource feedback which leads to the formation of reflective behaviors. Reflection on the learning process and reflective behaviors are considered an integral part of autonomous learning (Benson, 2011; Little, 1991). In this study, reflective practices on the speeches are categorized as selfreflection, peer feedback, and Group Interactive Feedback (GIF) as described earlier. The reflective practices and the teacher's feedback based on a rubric after each speech constitute the multisource feedback which shaped the students' reflective behaviors. The students' capacity to reflect upon their learning is evident from the Overall Written Reflections findings (Theme 2). The findings from the questionnaire also revealed the increased use of metacognitive strategies which are essential to enhance the capacity to reflect. The formation of reflective behaviors can be explained as the provision of the multisource feedback, and the cyclical nature of the reflection process.

From the pool of multisource feedback, the students demonstrated the capacity to reflect and critically evaluated each of the feedback and formulated their overall reflection of the speeches. The students' improvement in each speech based on their plans is also a testament of such capacity.

Another explanation for the reflective behaviors could be the cyclical nature of the reflection process in the ALP (Figure 5). In other words, repetitive tasks allow for the habit formation. In the ALP, the students underwent the reflection process four times (for the four speeches throughout the semester). As such, the process allows the students to systemically plan, monitor, and evaluate their learning. The 
cyclical and repetitive nature of the reflection process is believed to facilitate the formation of the reflective behaviors which is significant to the development of learner autonomy.

\section{Figure 5}

The Reflection Process in the ALP

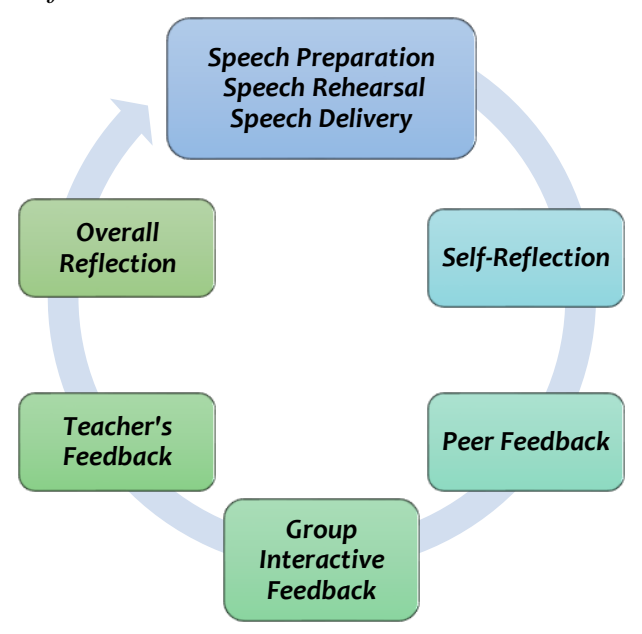

The implication is the significance of the reflection training. To explain, self-reflection training should be systematic so as to facilitate the reflection process. For instance, in the beginning, reflection guidelines should be provided so the students can reflect from the first step of the speech preparation to the last step of the speech delivery. Then, students can gradually reflect on their own at a more critical level.

Students also need to be trained to give and receive feedback. For the peer feedback training, to provide constructive feedback, the students should be encouraged to express their points of views while keeping in mind the characteristics of meaningful peer feedback. These include useful expressions and politeness features such as mood and tone. For the feedback recipients, open-mindedness and attentive listening training are called for, especially in Asian countries where criticism is not always well received.

Moreover, reflection training should aim at turning students into critical friends. Indeed, critical friends can provide both productive feedback and emotional support (Swatevacharkul, 2019). This means that collaborative learning should be a part of the teaching and learning activities in the English public speaking classrooms. By doing so, reflection activities can be more profound.

\section{Positive affect towards learning}

The third reason for the development of learner autonomy is that the students developed positive affect towards learning. Anxiety, confidence, and motivation are considered factors signifying the intensity of the students' affective filter (Krashen, 1982). Such affective filter can hinder learning. To lessen the affective filter, in the ALP, the training of the affective strategies focuses on turning negative thoughts about giving a speech into positive thoughts by the power of visualization. The premise was that if the students could imagine themselves delivering the speeches successfully, then they were at least half-way towards accomplishing the speech delivery. The ALP could help lower students' affective filter and create positive affect which enable the students to have self-encouragement to deliver the speeches. From the ALP, the positive affect towards learning can be enhanced from mutual motivation and satisfaction towards learning.

Mutual motivation, in this study, is a coined term to describe the motivation which was initially stimulated by others (the motivation to satisfy others, or extrinsic motivation) and consequently became internalized as the students discovered their own passion on the topic (to satisfy their own needs). When the students delivered the speeches on the topics that the audience would like to hear, they became more invested in the subject matter and more confident in their public speaking ability. The audience were motivated to listen, and the speakers were motivated to speak. Though intrinsic motivation is crucial to autonomous learning process, extrinsic motivation can also be internalized through support from teachers and peers (Ryan \& Deci, 2002; Yashima, 2014). Hence, mutual motivation is developed.

The positive affect towards the learning also emerged from the satisfaction and pride which resulted in the learner autonomy development. The students not only expressed more satisfaction on the speeches, but the satisfaction also stemmed from the praise and encouragement from the peer feedback. The sense of satisfaction signified the sense of achievement as it derived from both the students' feeling of knowing and the feedback from other sources (van Lier, 2014).

The implication is that the attention must be paid on the reinforcement of the positive affect which can be enhanced by explicit training of the affective strategies. The second implication is the role that the teacher plays in nurturing a pressure-free classroom climate. To lessen the pressure, the teacher must shift the students' attention on the progress they make on each of the speech rather than on the marks. When the students are aware of the progress as a result of their effort, they became more appreciative of their learning success over the grade received. Additionally, the teacher should cultivate friendly classroom atmosphere where classmates are supportive of each other.

\section{Identity construction}

The fourth reason for the development of learner autonomy is the students' identity construction. The findings in Theme 5 suggested that the emergence of self as the result of the ALP derived from the students' increased awareness and better 
understanding of self. This can be explained as the students explored ways to speak as themselves and transformed themselves from the multisource feedback.

Students' increased awareness of self can be discussed as the identity or self-discovery through the selection of the speech topic and the contents. In the ALP, the students were trained to develop selfconfidence by exploring their passions based on their past experiences and their wishes and dreams. In the process, the students learned about their identity as a person through their interests and background knowledge. Identity is understood as an individual sense of self which is in relation to some social context (Morita, 2004).

Indeed, when the students are encouraged to speak as themselves, they are more likely to feel involved and motivated to communicate (Ushioda, 2011). Motivation, in this sense, is directly linked to students' identity. Crucial to this study is the notion of transportable identity which is defined as "identities that are usually visible, that is, assignable or claimable on the basis of physical or culturally based insignia which furnish the intersubjective basis for categorization" (Zimmerman, 1998, p. 91). For instance, a student is not only a student. His or her transportable identity may include an anime collector, a popular budget travel blogger, and a swimmer on the university team.

The implication is that by bringing in the students' transportable identities into the classroom, the students can select the aspects of their identities to engage in order to express themselves (Ushioda, 2011). In other words, when the students are encouraged to speak as themselves in the target language regarding their preferred transportable identities, the motivational impact on their learning is significantly increased. By definition, autonomous learners are motivated learners (Ushioda, 1996). Therefore, identity is connected to learner autonomy.

\section{CONCLUSION}

To conclude, there are four points of discussions which could explain how the ALP contributed to the improvement of the level of learner autonomy and how learner autonomy is revealed.

First, learning strategies are prerequisites for learner autonomy, and the study's findings revealed that the types of the speech tasks can enhance the use and plans of learning strategies. Second, the students' capacity to reflect and their formation of reflective behaviors indicate the improvement of learner autonomy. Such capacity to reflect is found in both questionnaire and the Overall Written Reflections. Third, as the students developed more positive affect towards their learning, their level of learner autonomy is improved. Mutual motivation is also developed, and the students are more satisfied and prouder of their learning. Lastly, the students' construction of identity leads to the improvement in learner autonomy. Based on these four points of discussions, the impact of the ALP is that the students' level of learner autonomy can significantly improve.

Recommendation for further research includes an addition of a controlled group in the study to ensure the effectiveness of the ALP in English public speaking classrooms and a replication of the study should be done to ensure the reliability and generalizability of the findings.

\section{REFERENCES}

Benson, P. (1997). The philosophy and politics of learner autonomy. In P. Benson \& P. Voller (Eds.), Autonomy and independence in language learning (pp. 18-34). Longman.

Benson, P. (2007). Autonomy in language teaching and learning. Language Teaching, 40(1), 2140. https://doi.org/10.1017/S0261444806003958

Benson, P. (2011). Teaching and researching autonomy. Pearson.

Benson, P. (2012) Learner-centered teaching. In A. Burns \& Richards J. (Eds.), The Cambridge guide to pedagogy and practice in second language teaching (pp. 30-37). Cambridge University Press.

Boonkit, K. (2010). Enhancing the development of speaking skills for non-native speakers of English. Procedia-Social and Behavioral Sciences, 2(2), 1305-1309. https://doi.org/10.1016/j.sbspro.2010.03.191

Boonma, N. (Ed.). (2016). Proceedings of the $5^{\text {th }}$ $P S U$ education conference: Instructional design for autonomous learners. Prince of Songkla University.

Boonma, N., \& Swatevacharkul, R. (Eds.). (2018). Proceedings of the $8^{\text {th }}$ international conference on language and communication (ICLC): Reclaiming language, communication and culture for a sustainable society. National Institute of Development Administration (NIDA).

Borg, S., \& Al-Busaidi, S. (2012). Learner autonomy: English language teachers' beliefs and practices. ELT Journal, 12(7), 1-45. https://www.teachingenglish.org.uk/article/lear ner-autonomy-english-languageteachers \%E2\%80\%99-beliefs-practices

Chinpakdee, M. (2015). Thai EFL university students' perspectives on foreign language anxiety. Silpakorn University Journal of Social Sciences, Humanities, and Arts, 15(3), 61-90. https://so02.tcithaijo.org/index.php/hasss/article/view/44672\# : :text=Drawing\%20upon\%20the\%20Foreign $\% 20$ Language, and $\% 20$ outside $\% 20$ language $\% 2$ 0classroom\%20contexts. 
Cohen, A. D., Oxford, R. L., \& Chi, J. C. (2002). Language strategy use survey. University of Minnesota.

Cotterall, S. (1995). Readiness for autonomy: Investigating learner beliefs. Systems, 23(2), 195-205. https://doi.org/10.1016/0346251X(95)00008-8

Creswell, J. W., \& Plano Clark, V. (2011). Designing and conducting mixed methods research. SAGE Publications.

Dickinson, L. (1992). Learner autonomy 2: Learner training for language learning. Authentik

Dilbeck, K. E., McCroskey, J. C., Richmond, V. P., \& McCroskey, L. L. (2009). Self-perceived communication competence in the Thai culture. Journal of Intercultural

Communication Research, 38(1), 1-7. https://doi.org/10.1080/17475750903381598

Everhard, C. J. (2015). Investigating peer-and selfassessment of oral skills as stepping-stones to autonomy in EFL higher education. In C. Everhard \& L. Murphy (Eds.), Assessment and autonomy in language learning (pp. 114-142). Palgrave Macmillan.

Gardner, R. C., \& MacIntyre, P. D. (1992). A student's contributions to second language learning. Part I: Cognitive variables. Language Teaching, 25(4), 211-220. https://doi.org/10.1017/S026144480000700X

Holec, H. (1981). Autonomy in foreign language learning. Pergamon

Knowlton, D. S. (2000). A theoretical framework for the online classroom: A defense and delineation of a student-centered pedagogy. New Directions for Teaching and Learning, 84, 5-14. https://doi.org/10.1002/t1.841

Krashen, S. (1982). Principles and practice in second language acquisition. Prentice-Hall International.

Little, D. (1991). Learner autonomy 1: Definitions, issues, and problems. Authentik.

Little, D. (1995). Learning as dialogue: The dependence of learner autonomy on teacher autonomy. System, 23(2), 175-181. https://doi.org/10.1016/0346-251X(95)00006-6

Littlewood, W. (1996). “Autonomy": An anatomy and a framework. System, 24(4), 427-435. https://doi.org/10.1016/S0346251X(96)00039-5

Macaro, E. (1997). Target language, collaborative learning and autonomy. Multilingual Matters.

McCroskey, J. C. (1977). Oral communication apprehension: A summary of recent theory and research. Human Communication Research, 4(1), 78-96. https://doi.org/10.1111/j.14682958.1977.tb00599.x

McGraw, K. O., \& Wong, S. P. (1992). A common language effect size statistic. Psychological Bulletin, 111(2), 361-365. https://doi.org/10.1037/0033-2909.111.2.361
Morita, N. (2004). Negotiating participation and identity in second language academic communities. TESOL Quarterly, 38(4), 573603. https://doi.org/10.2307/3588281

Murase, F. (2015). Measuring language learner autonomy: Problems and possibilities. In C. J. Everhard \& L. Murphy (Eds.), Assessment and autonomy in language learning (pp. 35-63). Palgrave Macmillan.

Nakatani, Y. (2005). The effects of awarenessraising training on oral communication strategy use. The Modern Language Journal, 89(1), 76-91. https://doi.org/10.1111/j.00267902.2005.00266.x

National Qualifications Framework for Higher Education in Thailand. (2006, November 21). Implementation handbook. Ministry of Higher Education Science Research and Innovation Retrieved from http://www.mua.go.th/users/tqfhed/news/Files News/FilesNews8/NQF-HEd.pdf

Nunan, D. (1999). Second language teaching \& learning. Heinle \& Heinle.

Nunan, D., \& Lamb, C. (2001). Managing the learning process. In D. Hall \& A. Hewings (Eds.), Innovation in English language teaching: A reader (pp. 27-45). Routledge.

Oxford, R. L. (1990). Language learning strategies: What every teacher should know. Newbury House

Oxford, R. L. (2003). Toward a more systematic model of 12 learner autonomy. In D. Palfreyman \& R. C. Smith (Eds.), Learner autonomy across cultures: Language education perspectives (pp. 75-91). Palgrave Macmillan.

Pennycook, A. (1997). Cultural alternatives and autonomy. In P. Benson \& P. Voller (Eds.), Autonomy and independence language learning (pp. 35-65). Longman.

Plangkham, B., \& Porkaew, K. (2012). Anxiety in English public speaking classes. LEARN Journal: Language Education and Acquisition Research Network, 5, 110-119. https://so04.tcithaijo.org/index.php/LEARN/article/download/ 102820/82368/

Ramadhiyah, S., \& Lengkanawati, N. S. (2019). Exploring EFL learner autonomy in the 2013 curriculum implementation. Indonesian Journal of Applied Linguistics, 9(1), 231-240. https://doi.org/10.17509/ijal.v9i1.15626

Reinders, H., \& White, C. (2016). 20 years of autonomy and technology: How far have we come and where to next? Language, Learning \& Technology, 20(2), 143-154. https://scholarspace.manoa.hawaii.edu/bitstrea m/10125/44466/1/20_02_reinderswhite.pdf

Ryan, R. M., \& Deci, E. L. (2002). Overview of self-determination theory: An organismic dialectical perspective. In E. L. Deci \& R. M. 
Ryan (Eds.), Handbook of self-determination research (pp. 3-33). University of Rochester.

Sa-Ngiamwibool, A. (2010). Enhancing autonomous learning for international communication in a Thai context. Scholar Journal, 2(1), 61-65. http://www.assumptionjournal.au.edu/index.ph $\mathrm{p} /$ Scholar/article/view/830/739

Smith, R. (2008). Learner autonomy. ELT Journal, 62(4), 395-397. https://doi.org/10.1093/elt/ccn038

Suwannoppharat, K., \& Chinokul, S. (2015). Applying CLIL to English language teaching in Thailand: Issues and challenges. Latin American Journal of Content and Language Integrated Learning, 8(2), 237-254. https://doi.org/10.5294/laclil.2015.8.2.8

Swatevacharkul, R. (2019). Promoting pre-service EFL teacher reflection: An investigation of reflection levels in Thai context. Indonesian Journal of Applied Linguistics, 9(2), 463-471. https://doi.org/10.17509/ijal.v9i2.20244

Ushioda, E. (1996). Learner autonomy 5: The role of motivation. Authentik.

Ushioda, E. (2011). Motivating learners to speak as themselves. In G. Murray, X. Gao \& T. Lamb (Eds.), Identity, motivation and autonomy in language learning (pp. 11-24). Multilingual Matters.

van Lier, L. (2014). Interaction in the language curriculum: Awareness, autonomy and authenticity. Routledge.

Wenden, A. (1991). Learner strategies for learner autonomy. Prentice Hall International.

Yamkate, K., \& Intratat, C. (2012). Using video recordings to facilitate student development of oral presentation skills. Language Education in Asia, 3(2), 146-158. https://doi.org/10.5746/LEiA/12/V3/I2/A03/Ya mkate_Intratat

Yashima, T. (2014). Self-regulation and autonomous dependency amongst Japanese learners of English. In G. Murray (Ed.), Social dimensions of autonomy in language learning (pp. 60-77). Palgrave McMillan.

Zimmerman, D. H. (1998). Discoursal identities and social identities. In C. Antaki \& S. Widdicombe (Eds.), Identities in talk (pp. 87106). Sage. 